\title{
Peran Promosi Kesehatan Dalam Edukasi Tenaga Kesehatan Di Masa Pasca Vaksinasi Covid-19 di Kabupaten Tanah Laut
}

\author{
Mahyuni Hidayat, Bornea Retno Mahalayati, Hanil Sadikin, \\ Marhaeni Fajar Kurniawati \\ Program pasca sarjana ilmu komunikasi Universitas Islam Kalimantan Muhammad Arsyad \\ Al Banjari, Indonesia \\ Email authors: mahyuni78@gmail.com, bornea.wijaya@yahoo.com, \\ hshanilsadikin@gmail.com, marhaeni.akbar@gmail.com
}

\begin{abstract}
ABSTRAK
Sejak ditetapkan oleh World Health Organisation (WHO) sebagai pandemic global, maka perlu keseriusan dalam penanganan virus Covid-19 ini. Promosi Kesehatan (Promkes) adalah salah satu langkah strategis yang harus dilakukan dalam menyebarluaskan informasi dan mengedukasi kemasyarakat tentang pencegahan dan penanganan Covid-19. Tenaga kesehatan sebagai ujung tombak dalam pelayanan kegiatan Promosi Kesehatan (Promkes) sangat dibutuhkan terlebih dalam masa pasca vaksinasi Covid-19. Dengan pemberian promkes yang benar akan meningkatkan kepercayaan masyarakat terhadap vaksinasi dan lebih memotivasi masyarakat dalam berdisiplin menerapkan protokol kesehatan. Dokter memiliki posisi strategis dalam kegiatan Promkes di Fasilitas Kesehatan Tingkat Pertama (FKTP) melalui pemberian komunikasi, informasi, dan edukasi saat melakukan tatalaksana pasien maupun dalam manajemen kegiatannya. Penelitian ini bertujuan menggambarkan peran tenaga kesehatan dalam kegiatan Promkes edukasi di FKTP pasca vaksinasi Covid-19. Penelitian deskriptif dilaksanakan pada bulan Januari sampai Maret 2021 dengan jumlah responden 30 tenaga kesehatan dokter di FKTP yang bekerjasama dengan Badan Penyelenggara Jaminan Sosial Kesehatan (BPJSK) meliputi Puskesmas, Klinik Pratama, maupun praktik dokter perorangan di Kecamatan Pelaihari, Kabupaten Tanah Laut. Data diambil melalui pengisian kuesioner, wawancara dan observasi, selanjutnya dianalisis secara deskriptif. Gambaran keterlibatan dokter dalam pelaksanaan promkes pasca vaksinasi Covid-19 adalah sebanyak 98\% telah melaksanakan promkes di FKTP, 82\% melakukan promkes kepada semua pasien, 90\% melaksanakan perencanaan promkes, dan konsisten dalam pelaksanaannya, 72\% melakukan monitoring dan evaluasi, hanya $16 \%$ yang melakukan pengkajian data dalam perencanaan.
\end{abstract}

Kata Kunci: Covid-19, Promosi kesehatan, Promkes, pasca vaksinasi, tenaga kesehatan

\section{PENDAHULUAN}

World Health Organisation (WHO) telah menetapkan Covid-19 sebagai pandemi global dan Pemerintah Indonesia telah menetapkan Covid-19 sebagai bencana nasional (bencana-non alam). Untuk itu perlu segera dilakukan intervensi tidak hanya dari sisi penerapan protokol kesehatan namun juga diperlukan intervensi lain yang efektif melalui upaya pemberian vaksinasi.

Berbagai negara, termasuk Indonesia, telah mengembangkan vaksin yang ideal dengan berbagai platform yaitu vaksin inaktivasi /inactivated virus vaccines, vaksin virus yang dilemahkan (live attenuated), vaksin vektor virus, vaksin asam nukleat, vaksin seperti virus (virus-like vaccine), dan vaksin subunit protein. Pemerintah Indonesia telah resmi mengumumkan tujuh jenis vaksin COVID-19 yang digunakan di Indonesia. Hal ini tertuang 
dalam Keputusan Menteri Kesehatan Nomor HK.01.07/ Menkes/12758/2020 tentang Penetapan Jenis Vaksin untuk Pelaksanaan Vaksinasi COVID-19.

Ketujuh vaksin tersebut adalah Vaksin Sinovac (China), Vaksin PT Bio Farma (Indonesia-China), Vaksin Novavax (Amerika), Vaksin Oxford-AstraZeneca (Inggris), Vaksin Pfizer-BioNTech (Amerika-Jerman), Vaksin Moderna (Amerika), Vaksin Sinopharm (UEA). Dari tujuh jenis vaksin Covid-19 yang digunakan di Indonesia, baru ada tiga vaksin yang stoknya telah diterima dan digunakan dalam pelaksanaan vaksinasi, yakni vaksin buatan Sinovac (China), PT Bio Farma (Indonesia), dan Oxford-AstraZeneca (Inggris). Di Kabupaten Tanah Laut vaksin yang digunakan adalah vaksin buatan Sinovac (China) dalam bentuk suntik.

Vaksinasi Covid-19 bertujuan untuk mengurangi transmisi/penularan Covid-19, menurunkan angka kesakitan dan kematian akibat Covid-19, mencapai kekebalan kelompok di masyarakat (herd immunity) dan melindungi masyarakat dari Covid-19 agar tetap produktif secara sosial dan ekonomi. Kekebalan kelompok hanya dapat terbentuk apabila cakupan vaksinasi tinggi dan merata di seluruh wilayah. Upaya pencegahan melalui pemberian program vaksinasi jika dinilai dari sisi ekonomi, akan jauh lebih hemat biaya apabila dibandingkan dengan upaya pengobatan. Kebijakan program vaksinasi Covid-19 telah tertuang dalam Peraturan Presiden (Perpres) Nomor 99 Tahun 2020 tentang pengadaan vaksin dan pelaksanaan vaksinasi dalam rangka penanggulangan pandemi Covid-19, (Kemenkes RI 7:2021).

Untuk mendukung pencegahan Covid-19 melalui vaksinasi dibutuhkan promosi kesehatan yang bertujuan memberikan informasi kesehatan terkait Covid-19 yang transparan dan berkesinambungan, serta yang paling penting adalah menggunakan bahasa sederhana sehingga mudah dipahami oleh masyarakat awam kemudian dapat dilaksanakan dalam kehidupan sehari-hari untuk membantu memutus mata rantai penyebaran virus ini (EUPHA et al, 2021).

Promosi kesehatan, di sisi lain dapat dilihat sebagai langkah strategis yang bisa menjadi fokus utama dalam mencegah dan atau meminimalisir peluang seseorang untuk terjangkit wabah penyakit tertentu (Breslow,1999;Brubaker,1983;King,1994). Nutbeam (1986: 115) menambahkan promosi kesehatan adalah langkah yang diterapkan pada seluruh populasi bukan hanya kelompok tertentu dalam konteks kehidupan sehari-hari, tujuannya adalah untuk meningkatkan kesehatan.

Definisi Promkes berdasar atas SK menteri Kesehatan Nomor 585 Tahun 2007 tentang Pedoman Pelaksanaan Promkes di Puskesmas adalah upaya untuk dapat meningkatkan kemampuan masyarakat melalui pembelajaran dari, oleh, untuk, dan bersama masyarakat agar mereka dapat menolong diri sendiri, serta mengembangkan kegiatan yang bersumber daya masyarakat, sesuai sosial budaya setempat dan didukung kebijakan publik yang berwawasan kesehatan. Promosi Kesehatan menurut WHO adalah proses memampukan orang untuk dapat meningkatkan pengendalian atas faktor-faktor penentu kesehatan sehingga dapat meningkatkan kesehatan mereka. Pengertian ini mengandung proses dan tujuan pemberdayaan diri. Dengan demikian, esensi promosi kesehatan adalah pemberdayaan agar mampu memelihara dan meningkatkan kesehatan, dengan partisipasi sebagai unsur pokok untuk mempertahankan tindakan promosi kesehatan. Ruang lingkup Promkes meliputi: penyuluhan kesehatan, pendidikan kesehatan, promosi/peningkatan pemasaran sosial, dan advokasi kesehatan serta pemberdayaan masyarakat.

Strategi Promkes paripurna menurut Kementerian Kesehatan RI meliputi 4, yaitu: (1) Pemberdayaan, sebagai upaya menumbuhkan dan meningkatkan pengetahuan, kemauan dan kemampuan individu, keluarga dan masyarakat untuk mencegah penyakit dan meningkatkan kesehatannya serta menciptakan lingkungan sehat dan berperan aktif dalam penyelenggaraan 
setiap upaya kesehatan; (2) Bina suasana/ dukungan sosial adalah upaya menciptakan suasana yang mendukung individu, keluarga dan masyarakat untuk mencegah penyakit dan meningkatkan kesehatannya serta menciptakan lingkungan sehat dan berperan aktif dalam penyelenggaraan setiap upaya kesehatan; (3) Advokasi: upaya/proses yang terencana untuk mendapat komitmen dan dukungan dari pihak terkait agar klien/masyarakat berdaya untuk mencegah dan juga meningkatkan kesehatannya serta menciptakan lingkungan sehat; dan (4) Kemitraan: hubungan (kerjasama) antara dua pihak atau lebih, berdasar atas kesetaraan, keterbukaan, dan juga saling menguntungkan (memberi manfaat) untuk mencapai tujuan bersama berdasar atas kesepakatan, prinsip, dan peran masing-masing.

Penelitian di Kabupaten Tanah Laut oleh Bornea dan kawan-kawan telah menemukan hambatan pelaksanaan promkes pasca vaksinasi Covid-19 yaitu keterbatasan sumber daya manusia (SDM) dan pendanaan sehungga hanya 40\% Fasilitas Kesehatan Tingkat Pertama (FKTP) yang melaksanakan Promkes pasca vaksinasi Covid-19. Penelitian ini juga melaporkan hanya $8 \%$ pasien yang menyatakan sudah menerima Promkes pasca vaksinasi Covid-19. Penelitian di FKTP Puskesmas Pelaihari Kabupaten Tanah Laut tahun 2021 menunjukkan bahwa capaian perilaku disiplin protokol kesehatan di wilayah tersebut masih rendah. Hal ini berhubungan dengan jumlah angka pasien positif Covid-19 dirawat yang berasal dari Kecamatan Pelaihari masih merupakan pasien terbanyak dibandingkan dengan sebelas kecamatan lainnya di Kabupaten Tanah Laut.

Kendala dalam pelaksanaan promotif dan preventif dikarenakan kurangnya kualitas dan kuantitas sumber daya manusia, sarana dan prasarana di FKTP, strategi pengembangan organisasi promkes, serta sikap pasien dan kepatuhan warga yang masih kurang disiplin terhadap protokol kesehatan. Kualitas SDM yang masih perlu diperbaiki di antaranya pengetahuan tentang metode dan materi promkes. Beberapa keadaan tersebut mengakibatkan pelaksanaan kegiatan promotif dan preventif belum dilaksanakan secara maksimal di layanan primer FKTP.

Berdasarkan data kasus Covid-19 per Januari 2021 di Kabupaten Tanah Laut telah menyentuh 2.000 kasus dengan penambahan lebih dari 100 kasus positif pada bulan Januari 2021. Peningkatan jumlah kasus Covid-19 terbanyak ada di Kecamatan Pelaihari. Hal tersebut sebagai akibat pola hidup yang tidak sehat, kurangnya disiplin protokol kesehatan, mengindikasikan perlunya peningkatan kegiatan promotif dan preventif.

Program Promkes merupakan salah satu program wajib di Puskesmas, meski demikian sebanyak $70 \%$ puskesmas di Kabupaten tanah Laut belum mempunyai tenaga dengan kualifikasi promkes sehingga tenaga kesehatan yang menjalankan program promkes adalah perawat, bidan, dan sanitarian.

Dokter sebagai tenaga kesehatan memiliki peran yang strategis dalam promkes, yaitu memampukan orang dalam meningkatkan pengendalian atas determinan kesehatan dalam rangka meningkatkan kesehatan terutama saat pemeriksaan pasien, sedangkan FKTP sebagai gate keeper juga memiliki peran yang strategis dalam program promotif dan preventif. Kedua kondisi tersebut menjadikan dokter yang bertugas di FKTP memiliki peran yang sangat strategis dalam menjalankan program promotif dan preventif. Luft et all (2017) menyatakan peran dokter dalam promkes adalah sebagai advokat, yaitu memperjuangkan dukungan politik terhadap pencapaian kesehatan masyarakat. Meski demikian peran dokter dalam promkes masih rendah disebabkan oleh faktor struktural meliputi keterbatasan waktu, masalah remunerasi, kebijakan politik yang terfragmentasi misalnya belum ada pedoman baku terkait promkes pasca vaksinasi Covid-19, dan rendahnya pelatihan promkes untuk dokter umum. Penelitian ini untuk mengetahui pengetahuan, sikap, serta pelaksanaan Promkes oleh dokter sebagai tenaga kesehatan yang bekerja di FKTP di Kota Pelaihari. 
Dengan demikian, diharapkan mampu memberikan pertimbangan bagi penentu kebijakan dalam merencanakan program promkes di FKTP.

\section{METODE PENELITIAN}

Penelitian deskriptif dilakukan pada bulan Januari sampai Maret 2021. Jumlah responden didapatkan dari penghitungan dengan rumus dua proporsi sebanyak 10 tenaga kesehatan dokter, responden dipilih menggunakan tehnik concecutive sampling dengan kriteria dokter yang bekerja di FKTP yang bekerja sama dengan BPJS meliputi dokter kepala puskesmas, dokter fungsional puskesmas, dokter praktik perorangan, dan dokter pelaksana di klinik pratama. Setiap 1 FKTP dipilih 1 responden dokter pelaksana, sedangkan khusus puskesmas diambil 2 dokter 1 dokter pelaksana dan 1 kepala puskesmas. Data Penelitian diambil melalui wawancara menggunakan panduan wawancara serta kuesioner untuk mengali peran atau tindakan yang dilakukan oleh dokter dalam pelaksanaan promkes pasca vaksinasi Covid-19. Kuesioner penelitian terdiri atas 2 bagian, bagian pertama menanyakan data identitas, bagian kedua menanyakan menanyakan perilaku/peran yang dilakukan terkait strategi promkes yang terdiri atas advokasi, pemberdayaan dan bina suasana dan kemitraan serta keterlibatan responden dalam manajemen kegiatan promkes meliputi perencanaan, pelaksanaan dan evaluasi kegiatan. Bagian 2 terdiri atas 7 pertanyaan tertutup dan 1 pertanyaan terbuka yang kemudian diperdalam melalui wawancara mendalam. Pengambilan data dilakukan oleh enumerator yang telah dilatih tentang cara pengambilan data. Data kuesioner bagian 1 dan 2 diolah menggunakan SPSS, sedangkan hasil wawancara ditranskrip dan dikelompokkan berdasar atas variabel penelitian. Keseluruhan data dianalisis secara deskriptif.

\section{HASIL DAN PEMBAHASAN}

Kota Pelaihari sebagai pusat pemerintahan Kabupaten Tanah Laut mempunyai fasilitas kesehatan yang cukup lengkap, jumlah FKTP di Kota Pelaihari adalah 37, terdiri atas 5 puskesmas, 15 puskesmas pembantu, 2 puskesmas keliling, 5 dokter umum praktik perorangan, dan 10 klinik pratama. Pada penelitian ini didapatkan responden 30 dokter yang bekerja di FKTP yang bekerjasama dengan BPJS baik di Puskesmas, klinik swasta, maupun praktik perorangan di Kota Pelaihari, baik milik pemerintah maupun swasta. Sebagian besar responden berusia lebih dari 30 tahun dan telah bekerja lebih dari 5 tahun di fasilitas kesehatan saat penelitian dilaksanakan. Dokter yang berpendidikan terakhir S-2, meliputi 5 orang lulusan S-2 Biomedik dan 1 orang adalah lulusan S-2 peminatan Promosi kesehatan.

Seluruh responden menyatakan sudah melaksanakan promkes dalam melaksanakan tugas sehari-hari. Variasi peran yang dilakukan responden dalam kegiatan promosi kesehatan antara lain sebagai edukator dalam Komunikasi, Informasi, dan Edukasi (KIE), pelaksana pemberdayaan, dan advokat dalam mewujudkan bina suasana, dan kemitraan serta terlibat dalam pengelolaan kegiatan promkes dilihat dari aspek perencanaan, monitoring dan evaluasi kegiatan. Hasil analisis kuesioner dan wawancara mendalam tentang peran dokter umum pada kegiatan promkes yang dilakukan di FKTP di Kota Pelaihari didapatkan bahwa seluruh responden pernah terlibat dalam kegiatan promosi kesehatan. Keterlibatan responden pada kegiatan promosi kesehatan pasca vaksinasi Covid-19 antara lain sebagai edukator dalam KIE, penyuluh, managemen kegiatan, dan beberapa strategi promkes.

Keterlibatan dokter dalam promosi kesehatan masih terbatas pada strategi pemberdayaan baik melalui konseling, maupun penyuluhan. Hanya 2\% sampai $20 \%$ dokter yang terlibat dalam strategi kemitraan, advokasi, dan bina suasana. Meskipun keterlibatan dokter di dalam manajemen kegiatan dalam perencanaan sudah $50 \%$ atau lebih, namun 
berdasar atas hasil wawancara mendalam, perencanaan kegiatan hanya terkait persiapan materi yang akan disampaikan, penjadwalan kegiatan dan tempat pelaksanaan. Hanya sebagian kecil (14\%) dokter yang mempertimbangkan data penyakit sebagai bahan perencanaan kegiatan promkes. Monitoring dan evaluasi promkes telah dilaksanakan oleh sebagian besar responden (72\%), namun sebagian besar indikator yang dinilai hanya terbatas pada indikator proses dan output, misalnya jumlah masyarakat yang hadir, jumlah kegiatan yang terlaksana, jumlah warga yang aktif bertanya serta jumlah warga yang menjawab benar saat diberikan pertanyaan secara langsung maupun melalui post-test. Terdapat $8 \%$ dokter yang melakukan penilaian indikator outcome dan impact, yaitu perubahan perilaku masyarakat di wilayah kerjanya serta jumlah kunjungan pasien yang sakit di FKTP.

\section{KESIMPULAN}

Hasil analisis data tentang peran dokter umum dalam kegiatan promkes pasca vaksinasi Covid-19 di Kota Pelaihari dinyatakan bahwa ada 98\% dokter sudah melaksanakan promosi kesehatan pasca vaksinasi Covid-19 melalui KIE yang diberikan kepada pasien, keluarga, dan juga masyarakat. KIE merupakan bagian dalam strategi pemberdayaan, hal ini sesuai dengan salah satu syarat "five star doctor" yang dinyatakan WHO, yaitu sebagai kommunikator (Murtagh, 2011). WHO mendefinisikan KIE sebagai pendekatan yang dilakukan untuk mengubah atau memperkuat seperangkat perilaku sekelompok masyarakat terkait sebuah masalah dalam kurun waktu yang telah ditentukan, (Sachdeva, 2015). Sasaran KIE sesuai dengan lingkup pelaksanaan KIE meliputi individu, kelompok dan masyarakat luas. Komunikasi, informasi, dan edukasi bertujuan meningkatkan pengetahuan dan perilaku yang mendukung kesehatan melalui penyampaian pesan dan informasi menggunakan media promosi yang tepat, (Sachdeva, 2015). Komunikasi, informasi, dan edukasi yang dilakukan oleh responden meliputi KIE individu melalui konsultasi dan KIE kelompok dan masyarakat melalui penyuluhan dan kampanye baik di dalam maupun di luar FKTP. Komunikasi, informasi, dan edukasi dapat meningkatkan pengetahuan dan sikap positif yang akhirnya dapat memberikan motivasi dalam perubahan perilaku kesehatan yang lebih baik, (Setianingsih, 2017). Selain itu, KIE kepada pasien yang diberikan oleh provider kesehatan dalam hal ini dokter, dinilai lebih efektif dibanding dengan educator lain sebab dalam pandangan pasien dokter merupakan sumber informasi kesehatan yang paling terpercaya, (Oberg, 2009). Peningkatan kemauan, dan kemampuan untuk hidup sehat merupakan tujuan pemberdayaan, sedangkan pendampingan tenaga kesehatan melalui KIE rutin dan kunjungan rumah tentunya akan meningkatkan motivasi untuk perubahan perilaku menjadi lebih baik, (Kemenkes RI, 2011). Pengaruh KIE lebih kuat dalam menimbulkan perubahan bila didukung dengan ketersediaan fasilitas dan juga lingkungan yang mendukung perubahan yang diciptakan melalui tiga strategi (bina suasana, kemitraan, serta advokasi), (Kemenkes RI, 2011). Ketiga strategi tersebut memperkuat strategi pemberdayaan untuk menjamin sustainabilitas perubahan perilaku sehingga menghasilkan derajat kesehatan masyarakat yang lebih baik, (Sachdeva, 2015). Peran dokter pada ketiga strategi tersebut masih cukup rendah, meskipun Peckham dkk. menyatakan bahwa dokter berperan lebih kuat dalam mengadvokasi pengambil kebijakan untuk memberikan dukungan bagi program kesehatan yang diterapkan. Kemitraan dalam promkes menjamin keberlangsungan promkes sebagai upaya peningkatan perilaku kesehatan, (Costello, 2015). Bina suasana memberikan dukungan berupa lingkungan yang kondusif untuk perubahan perilaku menjadi lebih baik. Keterlibatan para dokter dalam ketiga strategi tersebut rendah, menjadikan program promkes hanya dilakukan oleh penanggung jawab promkes, sehingga hasil yang diperoleh kurang optimal. Penggunaan 
informasi di dalam perencanaan menjadikan program lebih tepat sasaran serta menunjang keberhasilan strategi advokasi, (Peral, 2015).

Dokter memiliki peran dalam pelaksanaan promkes di FKTP terutama dalam pelaksanaan KIE kepada pasien, keluarga, maupun kepada masyarakat. Keterlibatan dokter masih perlu ditingkatkan dalam strategi pemberdayaaan, kemitraan, bina suasana, serta advokasi untuk membuat perubahan perilaku masyarakat ke arah yang lebih baik.

Promosi kesehatan secara umum adalah peran dari seluruh tenaga kesehatan. Dengan melakukan promkes yang persuasif dan mudah dipahami masyarakat akan meningkatkan kesadaran masyarakat dalam menjaga kesehatan. Promkes pasca vaksinasi Covid-19 sangat diperlukan agar warga yang sudah menerima vaksin tetap disiplin menjaga kesehatan dan menerapkan protocol kesehatan. Jangan sampai vaksin yang diterima warga menjadi kesimpulan pribadi bahwa vaksin Covid-19 adalah tameng pelindung yang tak tertembus oleh virus tersebut. Dengan pemberian promkes pasca vaksinasi Covid-19 yang benar, tenaga kesehatan sangat berperan dalam memotivasi warga yang belum menerima vaksin agar tidak was-was dan tidak takut di vaksin.

Kepada peneliti selanjutnya semoga hasil penelitian ini bermanfaat dan bisa menjadi pendukung dalam melanjutkan penelitianserupa dengan sampling dan metode penelitian berbeda susuai dengan kebutuhan.

\section{DAFTAR PUSTAKA}

Costello M, Taylor J, O'Hara L. Impact evaluation of a health promotion-focused organisational development strategy on a health service's capacity to deliver comprehensive primary health care. Aust J Prim Health. 2015;21(4):444-9.

Dewi RK, Nuryadi, Sandra C. Identifikasi pelayanan promotif pada fasilitas kesehatan tingkat pertama program Jaminan Kesehatan Nasional. e-Jurnal Pustaka Kesehatan 2016; 4:307-15

Kemenkes RI. Hasil Utama Riskesdas 2018. Jakarta: Kemenkes RI; 2018

Kementerian Kesehatan RI. Promosi kesehatan di daerah bermasalah kesehatan. Edisi ke-1. Jakarta: Kemenkes RI; 2011

Luft LM. The essential role of physician as advocate : how and why we pass it on. Can Med Educ J. 2017;8:e109-e116

Keputusan Direktur Jenderal Pencegahan dan Pengendalian Penyakit Nomor HK.02.02/4/1/2021 Tentang Petunjuk Teknis Pelaksanaan Vaksinasi Dalam Rangka Penanggulangan Pandemi Corona Virus Disease 2019 (Covid-19).

Moreno-Peral P, Conejo-Cerón S, Fernández A, Berenguera A, Martínez-Andrés M, PonsVigués $M, d k k$. Primary care patients' perspectives of barriers and enablers of primary prevention and health promotion - a meta-ethnographic synthesis. PLoS One. 2015;10(5):e0125004.

Murtagh JE. Paradigms of family medicine: Bridging traditions with new concepts; Meeting the challenge of being the good doctor from 2011. Asia Pac Fam Med. 2011;10:9

Oberg EB, Frank E. Physicians' health practices strongly influence patient health practices. J R Coll Physicians Edinb. 2009; 39(4):290-1

Peraturan Menteri Kesehatan Republik Indonesia Nomor 10 Tahun 2021 Tentang Pelaksanaan Vaksinasi Dalam Rangka Penanggulangan Pandemi Corona Virus Disease 2019 (Covid-19).

Sachdeva S, Kar H, Sachdeva R, Bharti B, Tyagi A. Information, education, and communication (IEC): A revisit to facilitate change. J Indian Acad Clin Med. 2015;16: 106-109 
Sa'adah, F., \& Syairozi, M. I. RENCANA PEMBANGUNAN WUJUD MELAJU DESA TANJUNG.

Setiyaningsih LA. Korelasi terpaan media kie (komunikasi, informasi dan edukasi) penanggulangan hiv dan aids dengan tingkat pengetahuan pekerja seks perempuan (studi kasus pekerja seks perempuan kabupaten malang). Nomosleca 2017;3:551-67

Suryani Y, Ratnawati. Gambaran pelaksanaan pelayanan BPJS kesehatan di fasilitas kesehatan tingkat pertama di Kota Semarang. Kebijakan Kesehatan Indonesia 2016;5:9-13

Syairozi, M. I., Pambudy, A. P., \& Yaskun, M. (2021). ANALISIS PENERAPAN GOOD GOVERNANCE DALAM SISTEM INFORMASI KEUANGAN DAERAH. Prosiding Penelitian Pendidikan dan Pengabdian 2021, 1(1), 49-59.

Zhou W. The Coronavirus Prevention Handbook 101 Science Based-Tips That Could Save Your Life. China: Guangzhou Medical University; 2020 